\title{
HUBUNGAN ANTARA PENGETAHUAN WANITA USIA SUBUR TENTANG DETEKSI KANKER SERVIKS DENGAN SIKAP DALAM PEMERIKSAAN METODE IVA DI PUSKEMAS SUNGAI DURIAN KABUPATEN KUBU RAYA TAHUN 2020
}

\section{Megalina Limoy ${ }^{1}$, Uswatun Hasanah ${ }^{2}$}

Akademi Kebidanan Panca Bhakti Pontianak

Email Korespendensi: limoy.elena@gmail.com

\begin{abstract}
Abstrak
Kanker serviks adalah tumor ganas yang tumbuh di dalam leher Rahim atau serviks. Penyakit kanker serviks menempati peringkat kedua diantara berbagai jenis kanker yang menyebabkan kematian pada perempuan di dunia. Kanker serviks disebabkan oleh Human Papilloma Virus yang biasanya menyerang wanita usia 35-55 tahun dengan tanda gejala keluar darah saat hubungan seksual dan setelah menopause. Dalam penelitian ini menggunakan metode analitik korelasi dengan pendekatan cross sectional, dengan jumlah sampel sebanyak 51 orang responden yaitu WUS usia 16-49 tahun yang hadir di Puskesmas Sungai Durian. Analisa data menggunakan Analisa univariat dan analisa bivariate. Hasil nilai Chi-Square sebesar 0,318 (p-value> 0,05) sehingga dapat disimpulkan bahwa tidak ada hubungan antara pengetahuan wanita usia subur tentang deteksi kanker serviks dengan sikap dalam pemeriksaan metode IVA di Puskesmas Sungai Durian Kabupaten Kubu Raya tahun 2020. Perlu adanya upaya untuk meningkatkan pengetahuan masyarakat tentang deteksi kanker serviks melalui penyuluhan sehingga dapat mencegah terjadinya kanker dengan melakukan pemeriksaan IVA.
\end{abstract}

Kata kunci: Pengetahuan, Deteksi Kanker Serviks, Pemeriksaan IVA, Puskesmas Sungai Durian

\begin{abstract}
Cervical cancer is a malignant tumor that grows inside the cervix or cervix. Cervical cancer ranks second among the various types of cancer that causes death in women in the world. Cervical cancer is caused by the Human Papilloma Virus which usually attacks women aged 35-55 years with signs of bleeding during sexual intercourse and after menopause. This study used correlation analytic method with a cross sectional approach, with a total sample of 51 respondents, namely women aged 16-49 years who attended the Sungai Durian Community Health Center. Data analysis used univariate analysis and bivariate analysis. The result of the Chi-Square value is 0.318 (p-value> 0.05), so it can be concluded that there is no relationship between the knowledge of women of childbearing age about cervical cancer detection with attitudes in the IVA method examination at Sungai Durian Public Health Center, Kubu Raya Regency in 2020. It is necessary efforts to increase public knowledge about cervical cancer detection through counseling so as to prevent cancer by performing IVA examinations.
\end{abstract}

Keywords: Knowledge, Cervical Cancer Detection, Iva Examination, Sungai Durian Community Health Ce Pendahuluan

Wanita usia subur (WUS) adalah wanita yang berusia 15-49 tahun baik yang berstatus kawin maupun yang belum kawin atau janda (BKKBN, 2011). Organ reproduksi pada wanita usia subur sudah matang dan berfungsi dengan baik. Usia subur terjadi antara usia 18 sampai 40 tahun, sering dihubungkan dengan masa subur.

${ }^{1}$ Dosen Akademi Kebidanan Panca Bhakti Pontianak

${ }^{2}$ Mahasiswa Akademi Kebidanan Panca Bhakti Pontianak
Wanita diusia ini harus lebih memperhatikan kondisi tubuhnya agar selalu dalam kondisi prima (Marmi, 2014).

Berdasarkan estimasi Globocan, International Agency For Research In Cancer (IARC) (2012), insiden kanker pada wanita di Indonesia 134/100.000, kanker serviks 
menempati urutan kedua dari kanker yang menyerang pada wanita. Kanker serviks mendapati insiden $17 / 100.000$ perempuan (Infodatin Kemenkes RI, 2016).

Penyakit kanker serviks merupakan penyakit dengan prevalensi tertinggi ke dua di Indonesia selain kanker yang menyerang pada wanita, di tahun 2013 yaitu kanker serviks $0.8 \%$. Provinsi Kepulauan Riau, provinsi Maluku Utara, dan provinsi D.I Yogyakarta memiliki prevalensi kanker serviks tertinggi yaitu berkisar 1,5\% (Pusdatin Kemenkes RI, 2013). Menurut Pusdatin Kemenkes RI (2013), prevalensi dan estimasi jumlah penderita kanker serviks pada penduduk perempuan di Kalimantan Barat di diagnosis dokter dengan jumlah $0,4 \%$ dan estimasi jumlah absolut $882 \%$ o (Kemenkes, 2016).

Kanker serviks disebabkan oleh virus Human papillomavirus (tipe 16 dan 18, terutama dengan aneuploidi) dan kemungkinan virus herpes tipe 2 ini merupakan organisme penyebab perkembangan displasia serviks yang dapat berakhir menjadi kanker kemudian hari (Nugroho dan Indra, 2014).terkena kanker servik dikarenakan masih produktif melakukan hubungan seksual. Kanker serviks.

Berdasarkan data Dinas Kesehatan Kubu Raya (2015), jumlah puskesmas yang ada di Kubu Raya sebanyak 20 diantaranya Puskesmas Sungai Durian, jumlah seluruh wanita usia subur yang ada di Kubu Raya sebanyak 117.334 orang dan yang melakukan pemeriksaan leher rahim $730(1 \%)$ orang dan yang hasil IVA (+) adalah $0 \%$. Sedangkan wanita usia subur yang terbanyak dari puskemas yang ada di Kubu raya adalah Puskesmas Sungai Durian dengan jumlah 21.704 orang, yang melakukan pemeriksaan leher rahim $142(1 \%)$ orang dan hasil IVA (+) adalah $0 \%$.

Kanker serviks biasanya menyerang pada wanita berusia 35-55 tahun karena pada usia ini puncak usia reproduksi wanita, sehingga akan menyebabkan gangguan kualitas hidup secara fisik, kejiwaan, dan kesehatan seksual (Indrawati, 2009). Oleh karena itu, diharapkan wanita dapat menjaga hygiene dan kesehatan reproduksinya agar terhindar dari penyakit.

\section{Metode}

Desain penelitian yang digunakan dalam penelitian ini adalah metode analitik korelasi yaitu suatu metode untuk menganalisis hubungan antar dua variabel dan menghubungkan ke dua variabel dengan pengujian hipotesis, dengan rancangan pendekatan Cross Sectional (penelitian yang diadakan dalam waktu yang bersamaan tetapi dengan subjek yang berbedaa-beda). Desain penelitian ini adalah model atau metode yang digunakan peneliti untuk melakukan suatu penelitian yang memberikan arah terhadap jalannya penelitian. Penelitian ini untuk melihat hubungan pengetahuan dan sikap wanita usia subur dalam deteksi kanker serviks dengan pemeriksaan IVA. Jumlah sampel sampel yang diperoleh adalah 51 orang. 


\section{Hasil dan Pembahasan}

Diagram 1 Analisa Univariat Variabel Pengetahuan

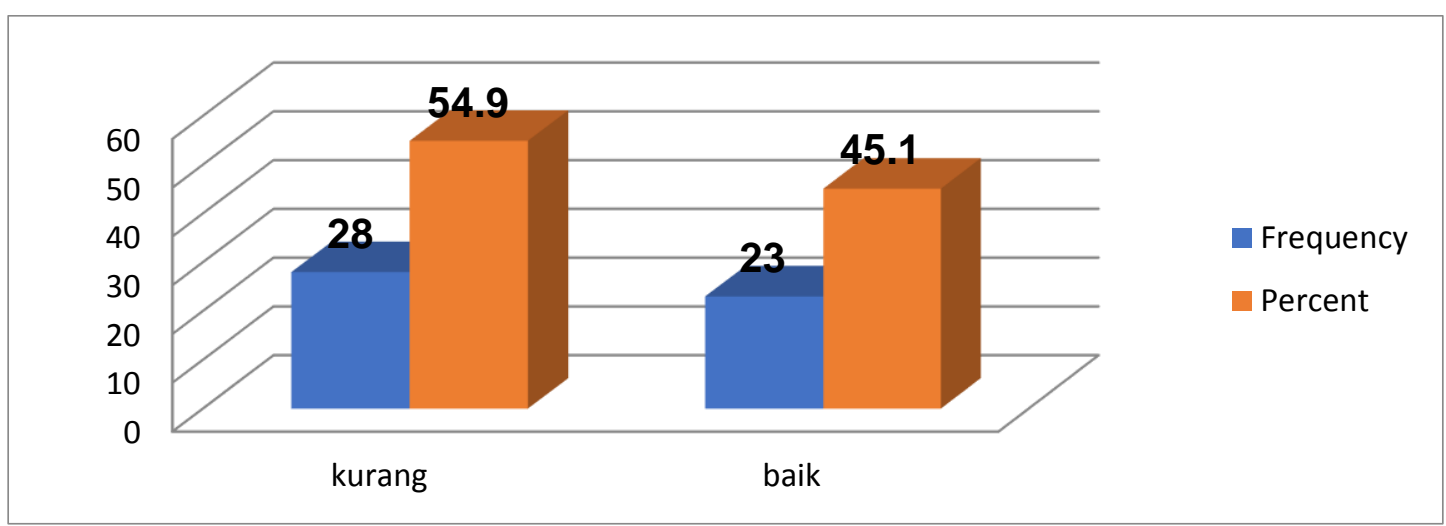

Berdasarkan diagram 1 diketahui bahwa sebagian dari responden berpengetahuan kurang yaitu 28 orang $(54,9 \%)$. Berdasarkan hasil jawaban responden diketahui juga bahwa sebagian besar dari responden yaitu 36 orang (70,6\%) menjawab benar pada Sikap wanita usia subur dalam pemeriksaan metode IVA. Pengisian kuesioner tentang sikap tentang pemeriksaan IVA sebanyak 13 pertanyaan. Setelah responden mengisi kuesioner kemudian peneliti menghitung jawaban responden dan nilai sikap responden tersebut dikategorikan yaitu mendukung $(\mathrm{x}>33,55)$ dan tidak mendukung $(\mathrm{x}<33,55)$.

Berikut ini merupakan hasil distribusi frekuensi kategori sikap responden terhadap pemeriksaan IVA yaitu sebagai berikut soal pengetahuan nomor 14 tentang waktu yang tepat untuk WUS melakukan pemeriksaan IVA. Dan hampir seluruh dari responden yaitu 43 orang $(84,3 \%)$ menjawab salah pada soal pengetahuan nomor 8 tentang tujuan dari deteksi kanker serviks.

Diagram 2 Analisa Univariat Variabel Sikap

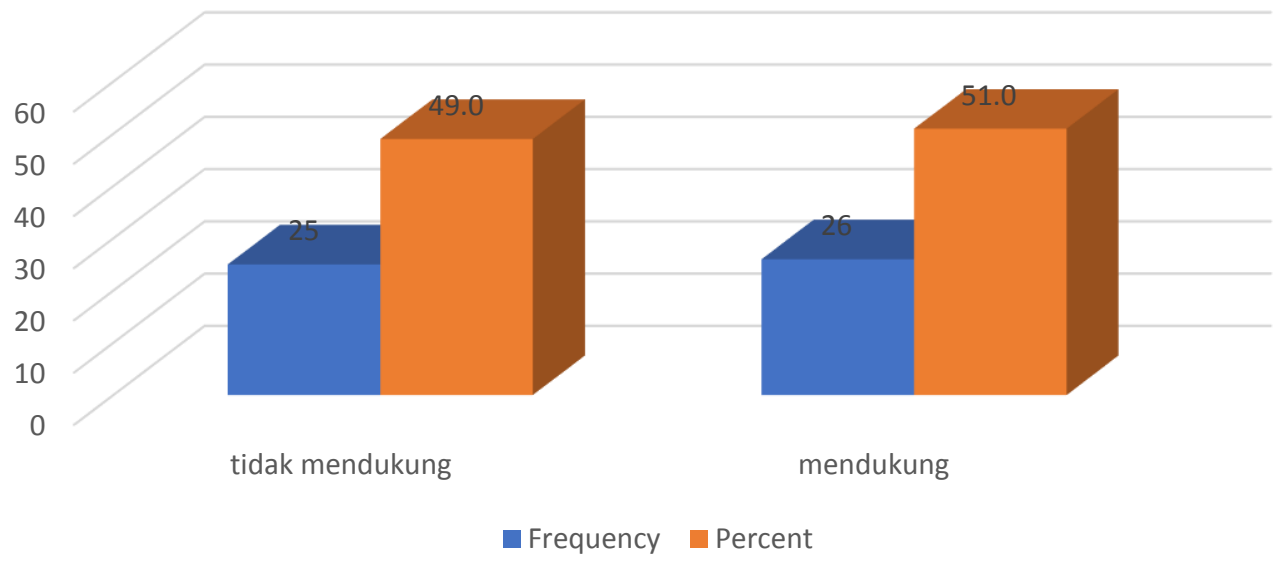

Berdasarkan diagram 4.2 diketahui bahwa sebagian responden yaitu 26 orang $(51 \%)$
Berdasarkan hasil jawaban responden diketahui juga bahwa sebagian besar dari responden yaitu 34 orang $(66,7 \%)$ menjawab 
sangat setuju pada soal nomor 1 tentang WUS sebaiknya melakukan deteksi adanya kanker leher rahim dan sebagian besar dari responden yaitu 31 orang $(60,8 \%)$ menjawab setuju pada soal nomor 2 tentang setiap wanita melakukan
Pemeriksaan IVA di Puskesmas dan 13 tentang dan Hasil pemeriksaan IVA sulit diketahui bagi seorang wanita yang mengalami kanker leher rahim.

Tabel 1 Analisa Bivariat

\begin{tabular}{lccccccc}
\hline & \multicolumn{4}{c}{ Sikap } & \multicolumn{2}{c}{ Total } & \multirow{2}{*}{ P.Value } \\
\cline { 2 - 6 } Pengetahuan & \multicolumn{2}{c}{ Tidak Mendukung } & \multicolumn{2}{c}{ Mendukung } & & \\
\cline { 2 - 6 } & $\mathrm{N}$ & $\%$ & $\mathrm{~N}$ & $\%$ & $\mathrm{n}$ & $\%$ & \\
\hline Kurang & 16 & 57,1 & 12 & 42,9 & 28 & 100 & \multirow{2}{*}{0,318} \\
Baik & 9 & 39,1 & 14 & 60,9 & 23 & 100 & \\
\hline
\end{tabular}

Berdasarkan hasil tabulasi silang diatas menunjukan bahwa sebagian responden $(42,9 \%)$ yaitu 12 orang berpengetahuan kurang dan bersikap mendukung terhadap pemeriksaan IVA sedangkan sebagian besar responden $(60,9 \%)$ yaitu 14 orang berpengetahuan baik dan bersikap mendukung terhadap pemeriksaan IVA. Sebagian responden $(57,1 \%)$ yaitu 16 orang berpengetahuan kurang dan bersikap tidak mendukung terhadap pemeriksaan IVA sedangkan sebagian kecil responden $(39,1 \%)$ yaitu 9 orang.

Pada tabel 1 menunjukkan bahwa pada analisa bivariat pada uji Chi-Square $\mathrm{P}$ value yang diambil adalah continuity correction Karena menggunakan tabel $2 \times 2$. Hasil uji statistik diperoleh nilai Chi-Square sebesar 0,318 (p-value> 0,05) sehingga dapat disimpulkan bahwa tidak ada hubungan antara pengetahuan wanita usia subur tentang deteksi kanker serviks dengan sikap dalam pemeriksaan metode IVA di Puskesmas Sungai Durian Kabupaten Kubu Raya tahun 2020.

Menurut Fitriani (2011), Pengetahuan merupakan hasil dari tahu, yang terjadi setelah orang melakukan pengindraan terhadap objek tertentu. Sebagian besar pengetahuan diperoleh melalui mata dan telinga. Pengetahuan atau kognitif merupakan domain yang sangat penting dalam membentuk tindakan seseorang.

Menurut Smart (2010), Kanker serviks atau yang lebih dikenal dengan istilah kanker leher rahim adalah tumbuhnya sel-sel tidak normal pada leher rahim. Sel-sel yang tumbuh tidak normal ini berubah menjadi sel kanker. Kanker leher rahim adalah kanker yang terjadi pada serviks uterus, suatu daerah pada organ reproduksi wanita yang merupakan pintu masuk kearah rahim yang terletak antara rahim (uterus) dan liang senggama (vagina).

Menurut KBBI (2014), deteksi adalah usaha menemukan dan menentukan keberadaan, anggapan, atau kenyataan. Deteksi kanker serviks adalah suatu usaha untuk menentukan tumor ganas yang tumbuh di dalam leher Rahim/ serviks (bagian terendah dari Rahim yang menempel pada puncak vagina).

Hal ini sesuai dengan hasil penelitian yang dilakukan oleh Nobellia Anggraini dengan judul Hubungan Tingkat Pengetahuan Tentang Kanker Serviks Dengan Perilaku WUS Melakukan Pemeriksaan IVA Di Puskesmas 
Banguntapan 1 Bantul Tahun 2015 bahwa tingkat pengetahuan tentang kanker serviks pada WUS sebagian besar adalah cukup yaitu sebanyak 23 orang $(69,6 \%)$ dan sangat sedikit dari responden berpengetahuan kurang yaitu 4 orang $(12,1 \%)$.

Hal ini tidak sesuai dengan hasil penelitian yang dilakukan oleh Nungki Marcellia Utami dengan judul Hubungan Tingkat Pengetahuan Pasangan Usia Subur Dengan perilaku Deteksi Dini Kanker Serviks di Wilayah Kerja Puskesmas Sangkrah Kecamatan Pasar Kliwon Surakarta Tahun 2013 bahwa tingkat pengetahuan responden menunjukkan sebagian besar responden memiliki kategori pengetahuan tinggi yaitu sebanyak 53 orang $(62 \%)$ dan sebagian kecil dari responden berpengetahuan sedang sebanyak 32 orang (38\%),

Menurut peneliti berdasarkan hasil pengetahuan responden kurangnya pengetahuan WUS tentang deteksi kanker serviks disebabkan ketidaktahuan tentang tujuan deteksi kanker serviks dan pada saat dilakukan penyuluhan oleh Puskesmas wanita usia subur hanya sedikit yang mengikuti penyuluhan.

Berdasarkan tabel tabulasi silang menunjukan bahwa sebagian responden $(42,9 \%)$ yaitu 12 orang berpengetahuan kurang dan bersikap mendukung terhadap pemeriksaan IVA $(42,9 \%)$ sedangkan sebagian besar responden yaitu 14 orang berpengetahuan baik dan bersikap mendukung terhadap pemeriksaan IVA (60,9\%). Pada analisa bivariat pada uji Chi-Square $\mathrm{P}$ value yang diambil adalah continuity correction Karena menggunakan tabel 2x2. Hasil uji statistik yang diperoleh nilai Chi-Square sebesar 0,318 (p-value> 0,05) sehingga dapat disimpulkan bahwa tidak ada hubungan antara pengetahuan wanita usia subur tentang deteksi kanker serviks dengan sikap dalam pemeriksaan metode IVA di Puskesmas Sungai Durian Kabupaten Kubu Raya tahun 2017.

Hal ini sesuai dengan penelitian yang dilakukan Nobellia Anggraini tahun 2015, yang berjudul "Hubungan Tingkat Pengetahuan Tentang Kanker Serviks Dengan Perilaku WUS Melakukan Pemeriksaan IVA Di Puskesmas Banguntapan 1 Bantul Tahun 2015”, dengan metode survey deskriptif analitik dengan pendekatan cross sectional. Hasil penelitian responden dengan tingkat pengetahuan kurang yang tidak pernah melakukan pemeriksaan IVA sebanyak 4 orang $(12,1 \%)$ dan yang melakukan pemeriksaan IVA sebanyak $0(0 \%)$. Sedangkan tingkat pengetahuan cukup yang tidak melakukan pemeriksaan IVA sebanyak 17 orang $(51,5 \%)$ dan yang melakukan pemeriksaan sebanyak 12 orang (36,3\%). Hasil uji statistik p-value $0,271>\alpha 0,05$, sehingga dapat disimpulkan bahwa tidak ada hubungan yang signifikan antara pengetahuan tentang kanker serviks dengan perilaku WUS melakukan pemeriksaan IVA di Puskesmas Banguntapan 1 Bantul tahun 2015.

Menurut peneliti sebagian dari responden (42,9\%) berpengetahuan kurang dan memiliki sikap mendukung dikarenakan kurangnya mendapat informasi yang baik dan jelas tentang deteksi kanker serviks meskipun telah diberikannya penyuluhan namun masih banyak WUS yang tidak mendapat infomasi tersebut 
seperti jawaban responden pada kuesioner pengetahuan. Sedangkan sikap yang mendukung terhadap pemeriksaan IVA dikarenakan perlunya melakukan deteksi kanker serviks seperti jawaban responden dalam pengisian kuesioner sikap.

Pengetahuan merupakan domain yang sangat penting untuk terbentuknya tindakan seseorang. Pengetahuan diperlukan sebagai dorongan fisik dalam menumbuhkan rasa percaya diri maupun dengan dorongan sikap perilaku setiap orang sehingga dapat dikatakan bahwa pengetahuan merupakan stimulasi terhadap tindakan seseorang, sedangkan sikap adalah reaksi atau respon yang masih tertutup dari seseorang terhadap suatu stimulus atau objek yang melibatkan faktor pendapat dan emosi yang bersangkutan.

\section{Kesimpulan}

Tidak ada hubungan antara pengetahuan wanita usia subur tentang deteksi kanker serviks dengan sikap dalam pemeriksaan metode IVA di Puskesmas Sungai Durian Kabupaten Kubu Raya tahun 2020. Perlu adanya upaya untuk meningkatkan pengetahuan masyarakat tentang deteksi kanker serviks melalui penyuluhan sehingga dapat mencegah terjadinya kanker dengan melakukan pemeriksaan IVA

\section{Daftar Pustaka}

Anggraini, Nobelia. 2013. Hubungan Tingkat PenmgetahuanTentang Kanker Serviks Dengan Perilaku WUS Melakukan Pemeriksaan IVA Di Puskesmas Banguntapan 1 Bantul Tahun 2015. http://.ejournal.akbidBantul.ac.id/index. php/jkk11/article/download/111/102SM.pdf di akses pada tanggal 24-02-2017 jam 22.51 WIB

Arikunto, Suharsimi. 2010. Prosedur Penelitian suatu Pendekatan Praktik. Rineka Cipta: Jakarta

Artiningsih, Ninik. 2011. Hubungan Antara Pengetahuan Dan Sikap WUS Dengan Pemeriksaan IVA Dalam Rangka Deteksi Dini Kanker Serviks Di Puskesmas Blooto Kecematan Prajurit Kulon Mojokerto https://eprints.uns.ac.id/7417/1/2160510 11201111551.pdf di akses pada tanggal 6-05-2017 jam 13.00 WIB

Badan Kesehatan Dunia WHO. 2015. Penderita Kanker

Serviks.http://www.suara.com/health/20 15/04/28/202546/penderita-kankerserviks- di-indonesia-tertinggi-di-dunia tanggal 24-2-2016 jam 21.07 WIB

Badan Kependudukan Keluarga Berencana. 2011. Batasan dan Pengertian MDK. http://aplikasi.bkkbn.go.id/mdk/Batasan MDK.aspx di akses pada tanggal 01-032017 jam 20.54 wib.

Dinas Kesehatan Pontianak. 2015. Profil Dinas Kesehatan Kota Pontianak. Pontianak: Dinkes

Fitiani, Sinta. 2011. Promosi Kesehatan. Yogyakarta: Graha Ilmu

Hidayat, A. Aziz Alimul. 2014. Metode Penelitian Kebidanan dan Teknik Analisis Data Contoh Aplikasi Studi Kasus. Jakarta: Salemba Medika

Ika, Nurma Zuliyanti. 2013.Hubungan Pengetahuan Ibu tentang Kanker Serviks dengan Sikap Pemeriksaan IVA. www.ejournal.akbid_purworejo.ac.id/indejkk11/article/download/111/102-SM.pdf di akses pada tanggal 24-02-2017 jam 22.51 WIB

Indrawati, Maya. 2009. Bahaya Kanker bagi wanita dan Pria. Jakarta: AV Publisher.

Maecelia, Nungki Utami. 2013. Hubungan Tingkat Pengetahuan Pasangan Usia Subur Dengan perilaku Deteksi Dini 
Kanker

Serviks. www.distrodoc.com/224676-hubungantingkat-pengetahuan-dengan-" perilakudeteksi/NASKAH_PUBLIKASI.pdf di akses pada tanggal 24-02-2017 jam 22.39 wib.

Marmi. 2014. Kesehatan Reproduksi. Yogyakarta: Pustaka Pelajar

Nugroho, Taufan dan Setiawan, Ari. 2010. Kesehatan Wanita Gender dan Permasalahanya. Yogyakarta: Nuha Medika

Nugroho, Taufan dan Indra Bobby Utama. 2014. Masalah Kesehatan Reproduksi wanita. Yogyakarta: Medika

Notoatmodjo, Soekidjo.2010. Metode Penelitian kesehatan. Jakarta: Rineka Cipta

2012. Metode Penelitian Kesehatan. Jakarta: Rineka Cipta

2010. Promosi Kesehatan Teori dan Aplikasi. Jakarta: Rineka Cipta

Priyo, Susanto Hastono dan Sabri, Luknis. 2010. Satistik Kesehatan. Jakarta: RajaGrafindo Persada

Purwoastuti, Endang dan Siwi, Elisabeth Walyani. 2015. Kesehatan Reproduksi Keluarga Berencana. Yogyakarta: Pustaka

Setiati, Eni. 2009. waspadai 4 Kanker Ganas Pembunuh Wanita. Yogyakarta: Andi Offset

Sugiyono. 2011. Statika untuk Penelitian. Bandung: AlfaBeta

Sujarweni, V. Wiratna. 2014. Metodelogi Penelitian Keperawatan. Yogyakarta: Gava Media

Susila san Suyanto. 2014. Metode Penelitian Cross Sectional Kedokteran dan Kesehatan. Klaten: Boss Script

Wawan, A dan Dewi M. 2010. Teori dan Pengukuran Pengetahuan, sikap dan perilaku manusia. Yogyakarta: Nuha
Medika

Pusat data dan informasi Kementrian Kesehatan. 2013. http://sehat.link/angkaprevalensi-kanker-di-indonesia.info di akses tanggal 24-2-2016 jam 19.52 WIB

Pusat Data dan Informasi Kementrian Kesehatan. 2013.Kanker Payudara. www.depkes.go.id/resources/download/ pusdatin/infodatin/infodatin-kanker.pdf tanggal 24-2-2016 jam 20.40 WIB 